\title{
Breeding and production performance profile of Black Bengal goats in rural areas of Mymensingh in Bangladesh
}

\author{
Islam AFMF, S Nahar, Tanni TSJ, Hoque MA, Bhuiyan AKFH*
}

Department of Animal Breeding and Genetics, Bangladesh Agricultural University, Mymensingh 2202, Bangladesh

\begin{abstract}
The present study was conducted to know the breeding and performance profile of Black Bengal goat in 4 upazila (Mymensingh Sadar, Fulbaria, Trishal and Muktagacha) of Mymensingh district. The data were collected using a pre-tested questionnaire from 100 goat rearers. The questionnaire included primary information about goat owners, total number of goats, color pattern, birth information, fate of male kids, weight of kids, breeding system and source of breeding males, breeding cost, litter size, kid mortality, some management parameters on goat and goat rearing system under rural condition. On an average, goat per family at Mymensingh district was found to be $3.56 \pm 1.77$ where the percentage of does and bucks were $90.61 \%$ and $9.39 \%$ respectively. Most of the farmers were found not to keep male kid for bad odor and difficult management and hence castrate them. Almost all farmers depend on natural mating to serve their does by passing a significant distance. The average service charge was

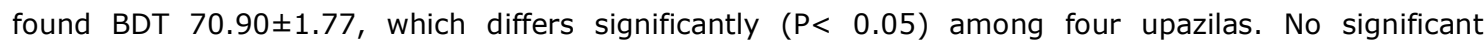
difference was found in performance of goats among four upazilas. The average body weight at 3 and 6 months of age of female goats were $4.67 \pm 0.15$ and $7.12 \pm 0.14 \mathrm{~kg}$ respectively. The average litter size was found $1.76 \pm 0.75$ and the average kid mortality rate was $12.88 \%$ in Mymensingh district. From this study, it became evident that acute shortage of Black Bengal breeding bucks exists in the rural areas which may represent the overall situation of the country.
\end{abstract}

Key words: breeding, performance, Black Bengal goat

Bangladesh Animal Husbandry Association. All rights reserved.

Bang. J. Anim. Sci. 2016. 45 (2): 46-51

\section{Introduction}

Black Bengal goats are dwarf goats and are known to be famous for its adaptability, higher disease resistant, fertility, fecundity, early sexual maturity, larger litter size, delicacy of meat and superior skin quality (Devendra and Burns 1983; Husain et al., 1998, Islam 2001). Out of 1005.60 million world goat population, Asia itself possesses about 597.15 million which is almost $59.38 \%$ of the total world population (FAO, 2013). Among the Asiatic countries, Bangladesh has got the fourth highest population of goats which accounted for about 25.61 million heads (BER, 2014). About 90 percent of goat population comprised the Black Bengal goats (Amin et al., 2001). The higher demand of meat and skin in the local as well as foreign markets focused the goat enterprise extremely prominent to the vulnerable group of people in the existing socioeconomic condition of the country (Husain, 1993).

*Corresponding author: bhuiyanbau@gmail.com
It is observed about $80 \%$ of the goats are being reared by the landless and marginal farmers living in the rural areas of the country. They generally follow the extensive management system, primarily with poor natural vegetation and crop stubbles, with or without any supplementation. More importantly, above $98 \%$ of Black Bengal goats are being managed in the traditional village system of the country (Husain et al.1998) where mature and quality breeding bucks are not available. Government has some breeding buck selling program at subsidized rate from government goat farms but those on-station bucks are not popular among the users. On the other hand, BRAC is in operation of an artificial insemination program in Black Bengal goat whose buck station is located in Shambuganj, Mymensingh but the said service could not be sustained in the whole country due to cost effectiveness. Therefore, quality bucks for breeding service is not available in rural villages. 
It was also reported that farmers were bound to depend on the community based buck breeding system with unknown pedigree. Almost $100 \%$ of the farmers in Lalmonirhat, Rangpur, Tangail and Khulna districts served their does naturally by these unknown pedigree and low quality breeding bucks (Khandoker et al., 2011). As a result, unplanned and haphazard breeding has been in operation in our country. In some cases, it is a matter of great concern that crossbreeding has been performed which not only decreases the purity but also leading to the genetic dilution of Black Bengal goats. On the other hand, due to unavailability of Black Bengal breeding bucks, the same buck has been used generation after generation. As a consequence, inbreeding depression may be increased which is ultimately responsible for the gradual decline of overall productivity of goat (Khandoker et al., 2011). In this context, the present study was conducted to identify current breeding practices and the performance of Black Bengal goats in rural areas of Mymensingh district.

\section{Materials and Methods}

The field experiment was conducted in four upazila of Mymensingh district viz. i) Sadar, ii) Fulbaria, iii) Muktagacha and iv) Trishal. In order to obtain field data a random door to door survey was conducted in the goat-owners households of the aforementioned regions. Data associated with live goat were taken directly from the goats in the farmers premises. Information from the farmers was collected through direct interviewing using a pre-tested questionnaire. The questionnaire included primary information about goat owners, total number of goats, coat color pattern, birth information, fate of male kids, body weights of kids at 3 and 6 month, breeding system and source of breeding males, breeding cost, some management parameters on goat and goat rearing system under rural condition.

Three traits such as body weight, litter size and kid mortality rate were studied in this experiment. The body weights of kids were measured out at 3 and 6 months respectively. Animals were weighed with the help of weighing balance. Number of live $\operatorname{kid}(s)$ born was considered in this study as litter size. Mortality of kids was referred to as the ratio of kid died at 3 month of age in respect to total number of kids born. All the data obtained from the four upazilas were organized, structured and analyzed using the ANOVA procedure under Statistical Analysis System (SAS) version 9.1.3 (2004).

\section{Results and Discussion}

\section{Categories of respondents}

Among 100 respondents 30, 30, 20 and 20 respondents were from Mymensingh Sadar, Fulbaria, Trishal and Muktagacha upazila respectively. Selected characteristics of the respondents - indicated that most of the respondents $(67 \%)$ were of young age group i.e. 15-29 years old (Table 1 ). Among respondents nearly one half farmers were illiterate (48\%) and only $6 \%$ farmers were highly educated (Table 1 ). About $49 \%$ of farmers were landless and most of the respondents were involved in agriculture occupation (52\%).

Table 1. Categories of respondents

\begin{tabular}{|c|c|c|c|}
\hline $\begin{array}{l}\text { Characteri } \\
\text { stics }\end{array}$ & $\begin{array}{l}\text { Scoring } \\
\text { method }\end{array}$ & Categories & $\begin{array}{l}\text { Respondents } \\
(\mathrm{N}=100) \text { No. } \\
\text { /percent }\end{array}$ \\
\hline \multirow[t]{3}{*}{ Age } & \multirow[t]{3}{*}{ Years } & Young (15 to 29 ) & 55 \\
\hline & & Middle (30 to 49 ) & 36 \\
\hline & & Old (50 and above & 9 \\
\hline \multirow[t]{4}{*}{ Education } & \multirow{4}{*}{$\begin{array}{l}\text { Year of } \\
\text { Schooling }\end{array}$} & Illiterate $(0)$ & 48 \\
\hline & & Primary (1 to 5 ) & 38 \\
\hline & & Secondary (6 to 10$)$ & 8 \\
\hline & & $\begin{array}{l}\text { Higher education (11 } \\
\text { and above) }\end{array}$ & 6 \\
\hline \multirow[t]{4}{*}{ Land Type } & \multirow[t]{4}{*}{ Acre } & Landless ( 0 to 0.49 ) & 49 \\
\hline & & Marginal (0.50-1.49) & 44 \\
\hline & & Small (1.5 to 2.49$)$ & 7 \\
\hline & & $\begin{array}{l}\text { Large( } 7.50 \text { and } \\
\text { above) }\end{array}$ & 0 \\
\hline \multirow[t]{5}{*}{ Occupation } & \multirow[t]{5}{*}{ Type } & Agriculture (1) & 52 \\
\hline & & Labour (2) & 6 \\
\hline & & Business (3) & 10 \\
\hline & & Service (4) & 6 \\
\hline & & Others (5) & 26 \\
\hline
\end{tabular}

\section{Goat per family}

The average goat per family at Mymensing Sadar, Fulbaria, Trishal and Muktagacha were found to be $3.26 \pm 0.283, \quad 3.1 \pm 0.343, \quad 4.40 \pm 0.372$, $3.85 \pm 0.399$ respectively. No significant difference was found in average goat per family among the upazilas. Trishal upazila had the highest density of Black Bengal goats compared to other upazilas 
whereas maximum and minimum numbers were 8 and 2 respectively (Table 2 ).

Table 2. Average goat per family

\begin{tabular}{lcccc}
\hline \multirow{2}{*}{ Upazila } & \multicolumn{2}{c}{ No. of goats per family } & \multirow{2}{P}{$\begin{array}{c}\mathbf{P} \\
\text { Value }\end{array}$} \\
\cline { 2 - 3 } & $\begin{array}{c}\text { Mean } \pm \text { SE } \\
(\mathrm{N})\end{array}$ & Maximum & Minimum & \\
\hline $\begin{array}{l}\text { Mymensingh } \\
\text { Sadar }\end{array}$ & $\begin{array}{c}3.26 \pm 0.28 \\
(30)\end{array}$ & 9 & 1 & \\
Fulbaria & $\begin{array}{c}3.1 \pm 0.34 \\
(30)\end{array}$ & 8 & 1 & \\
Trishal & $\begin{array}{c}4.40 \pm 0.37 \\
(20)\end{array}$ & 8 & 2 & $0.053^{*}$ \\
Muktagacha & $\begin{array}{c}3.85 \pm 0.39 \\
(20)\end{array}$ & 8 & 1 & \\
Overall & $\begin{array}{c}3.56 \pm 1.77 \\
(100)\end{array}$ & 9 & 1 & \\
\hline
\end{tabular}

"Non significant at $5 \%$ level.

\section{Sex distribution}

The percentage of does and bucks of Black Bengal goats in Mymensingh sadar and Fulbaria were $89 \%$ and $11 \%$ respectively and percentage of does and bucks in Trishal and Muktagacha were $93 \%$ and $7 \%$ respectively (Figure 1 : a-e) All the farmers $(100 \%)$ of four upazilas castrated their male kids. Alam (2006) reported a distribution of $55 \%$ doe, $5 \%$ buck and $40 \%$ wether of Black Bengal goat in Sylhet and Bogra. He also reported that $54 \%$ doe, $4 \%$ buck, $42 \%$ wether at Sylhet, $67 \%$ doe, $5 \%$ buck, $28 \%$ wether at Mymensingh and 58\% doe, 4\% buck, $38 \%$ wether at Bogra which are close to current findings.

\section{Fate of male kids}

The reasons opined by the farmers not keeping male kids for breeding bucks include bad odor $(81 \%)$ and difficult management $(19 \%)$ in four upazilas. Castration of male kids was done at less than one month of age (by $69 \%$ of goat rearers) and at less than 2 month of age (by $24 \%$ of goat rearers), whereas only 7 percent respondents castrated their male kids at less than 3 month of age in Mymensingh district (Table 3). Jana et al. (2014) conducted a study in Burdwan district of West Bengal and reported that castration of male kids was done at 5-7 weeks of age (by $76.67 \%$ of goat rearers) and at more than 7 weeks of age (by $14 \%$ goat rearers), whereas only 9.33 per cent respondents castrated their kids at 2 to 4 weeks of age. This fate of male kids could be considered as one of the main reasons behind lack of availability of quality bucks for breeding Black Bengal goats in the study area and country at large.

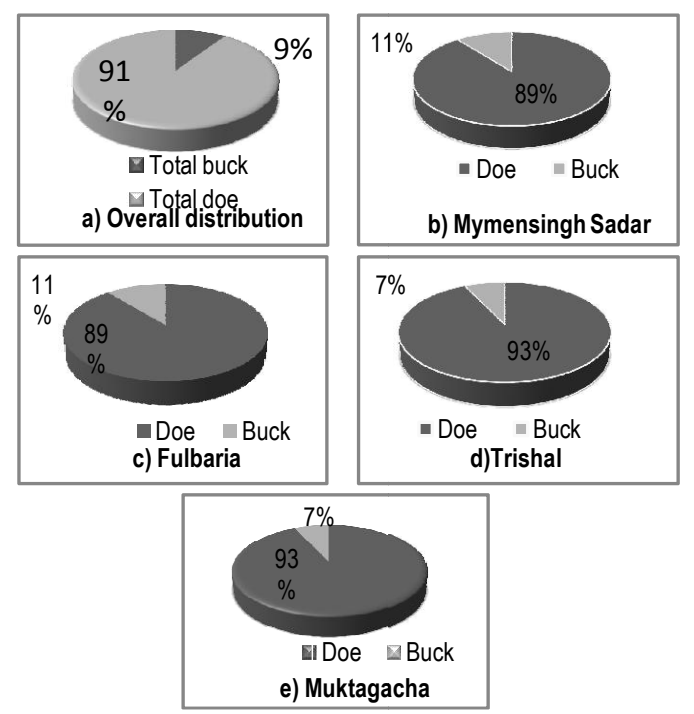

Figure 1. Distribution of Black Bengal goats according to sex in each upazila

\section{Breeding place for serving doe}

There was a scarcity of breeding bucks. The bucks available in the area were small and without any pedigree. Hence the farmers in the study area did depend on the community based buck breeding system.

Table 3. Time of castration of male kids

\begin{tabular}{llll}
\hline Upazila & $\begin{array}{l}\text { Less than } \\
\text { one month }\end{array}$ & $\begin{array}{l}\text { Less than } \\
\text { two month }\end{array}$ & $\begin{array}{l}\text { Less than } \\
\text { three month }\end{array}$ \\
\hline $\begin{array}{l}\text { Mymensingh } \\
\text { Sadar }\end{array}$ & $73.33 \%$ & 23.33 & 3.33 \\
Fulbaria & $66.67 \%$ & 26.67 & 6.67 \\
Trishal & $85.00 \%$ & $10.00 \%$ & $5.00 \%$ \\
Muktagacha & $55.00 \%$ & $45.00 \%$ & $0.00 \%$ \\
Overall & $69.00 \%$ & $24.00 \%$ & $7.00 \%$ \\
\hline
\end{tabular}

\section{Type of mating}

All respondents $(100 \%)$ in four upazilas were found to dependent on natural breeding for their does. There was no government or private AI worker in and around villages for doe servicing. So, they did depend on community based buck breeding system (Table 4 ). 


\section{Breed of buck used in servicing}

The bucks used for servicing does were Black Bengal goat in all the study areas with unknown records (Table 4 ).

Table 4. Different breeding criteria of goat in Mymensing district

\begin{tabular}{lllll}
\hline Criteria & $\begin{array}{l}\text { Mymensingh } \\
\text { Sadar }\end{array}$ & Fulbaria & Trishal & Muktagacha \\
\hline $\begin{array}{l}\text { Fate of } \\
\text { male kids }\end{array}$ & Castration & Castration & Castration & Castration \\
$\begin{array}{l}\text { Type of } \\
\text { Mating }\end{array}$ & Natural & Natural & Natural & Natural \\
$\begin{array}{l}\text { Service } \\
\text { station }\end{array}$ & Private & Private & Private & Private \\
Breed & Black & $\begin{array}{l}\text { Black } \\
\text { Bengal }\end{array}$ & $\begin{array}{l}\text { Black } \\
\text { Bengal }\end{array}$ & $\begin{array}{l}\text { Black } \\
\text { Bengal }\end{array}$ \\
\hline
\end{tabular}

Distance between breeding buck and does

It was observed that about $30 \%$ farmers had to pass a high distance (more than $3.0 \mathrm{~km}$ ) to bred their does in four upzilas of Mymensingh district whereas $20 \%$ farmers need to pass a medium distance $(1.0-3.0 \mathrm{~km})$ and rest of the $50 \%$ farmers have to pass a low distance (0.1-0.9 $\mathrm{km})$.

Table 5. Distance between breeding buck and does

\begin{tabular}{|c|c|c|c|}
\hline \multirow[t]{3}{*}{ Upazila } & \multicolumn{3}{|c|}{ Categories $^{*}(\%)$} \\
\hline & Low & Medium & High \\
\hline & $\begin{array}{c}(0.1-0.9 \\
\mathrm{km})\end{array}$ & $\begin{array}{c}(1.0-3.0 \\
\mathrm{km})\end{array}$ & $\begin{array}{c}\text { (More than } 3.0 \\
\text { km) }\end{array}$ \\
\hline $\begin{array}{l}\text { Mymensingh } \\
\text { Sadar }\end{array}$ & 67 & 33 & 0 \\
\hline Fulbaria & 33.33 & 33.33 & 33.33 \\
\hline Trishal & 100 & 0 & 0 \\
\hline Muktagacha & 0 & 0 & 100 \\
\hline Overall & 50 & 20 & 30 \\
\hline
\end{tabular}

*Data in the column indicates the respondent percentage $(\mathrm{N}=100)$ of four upazilas

The distances farmers need to cover between breeding buck and does in four upazilas are presented in Table 5. Khandoker et al. (2011) reported that about $58 \%$ farmers had to pass a long distance (more than $3.0 \mathrm{~km}$ ) to breed their does in Mymensingh district whereas $30 \%$ farmers need to pass a medium distance (1.0-3.0 $\mathrm{km}$ ) and only $12 \%$ have to pass a low distance (0.1-0.9 km). So, it is a general picture that farmers need to travel a reasonable distance to breed their does which causes wastage of time and energy of goat rearers.

\section{Service charge for breeding}

The average service charge was found BDT $70.90 \pm 1.77$ in Mymensingh district. There was significant $(P<0.001)$ difference in service charge in different upazila (Table 6 ). The highest service charge was found BDT $80.50 \pm 3.80$ in Muktagacha upazila and lowest service charge was found BDT 54 \pm 0.909 in Mymesnigh sadar which is shown in Table 6 . The service charge was high in the rural areas of Mukhtagacha upazila due to high scarcity of breeding buck.

Table 6. Average service charge in four upazila

\begin{tabular}{llll}
\hline Upazila & $\begin{array}{l}\text { Service charge in } \\
\text { TK. (Mean } \pm \text { SE) }\end{array}$ & P value & $\begin{array}{l}\text { Level of } \\
\text { significance }\end{array}$ \\
\hline $\begin{array}{l}\text { Mymensingh } \\
\text { Sadar }\end{array}$ & $54.00 \pm 0.909$ & & \\
Fulbaria & $75.33 \pm 3.73$ & $<0.0001$ & \\
Trishal & $80.00 \pm 2.63$ & & \\
Muktagacha & $80.50 \pm 3.80$ & & \\
Overall & $70.90 \pm 1.77$ & & \\
\hline
\end{tabular}

*** $=$ Significant at $0.1 \%$ level $(P<0.001)$.

\section{Production Performances of Black Bengal goats}

\section{Body weight}

The average body weights of female goat at 3 and 6 months of age were $4.67 \pm 0.15$ and $7.12 \pm 0.14 \mathrm{~kg}$ respectively which is shown in the Table 7. Body weights of goats did not significantly differ among four upazilas. Husain (1993) reported the body weight of kids at 3, 6, 9 and 12 month of age were $4.9 \pm 0.17,8.4 \pm 0.28$, $10.7 \pm 0.36$ and $12.8 \pm 0.2 \mathrm{~kg}$, respectively in Black Bengal goats which is almost similar with this study. Mia et al. (1993) reported birth weight, 6 month body weight and 12 month body weight to be $1.35,7.69$ and $11.28 \mathrm{~kg}$, respectively in Black Bengal goats of Bangladesh reared in intensive farm which is also almost similar with the study. The birth weight and weight at 3, 6 and 12 month of age in Black Bengal goats to be 1.13, 5.41, 7.96 and $12.12 \mathrm{~kg}$, respectively Kanaujia and Pander (1988) which is almost similar with study. In another investigation, the body weight of male and female Black Bengal goats at 3, 6, 9, 12 month were 5.08, 7.94, 10.71, 13.19 and 4.48, $7.27,9.90,12.47 \mathrm{~kg}$, respectively. 


\section{Litter size}

The average litter size in Black Bengal does were found $1.76 \pm 0.75$ in Mymensingh district (Table 7). No significant difference in litter size was observed among the does of four upazilas. Wilson (1989) reported that the litter size of goats under research station and traditional management conditions were ranged from 1.16 to 1.57 respectively which is lower than this study. Islam et al. (2009) found that litter size of Black Bengal does under semi intensive and scavenging system were $2.00 \pm 0.00$ and $2.33 \pm 0.33$, respectively which is higher than this study. The results of the present study are similar with Choudhury et al. (2012) where they reported that the litter size was highest in solid black $(1.67 \pm 0.54)$ does than Toggenburg pattern $(1.56 \pm 0.45)$ and Brown Bezoar (1.38 \pm 0.48$)$.

\section{Kid mortality rate}

The average kid mortality rate from birth to 3 month was $12.88 \%$ in Mymensingh district. The highest average kid mortality rate from birth to 3 month of age was $16 \%$ in Trishal upazila and lowest kid mortality was $10.71 \%$ in Muktagacha (Table 8). Tsedeke (2007) observed that kid mortality of Arsi Bali goats under traditional system was $12.2 \%$ which is nearly similar with the study. This result is similar with the findings of Singh et al. (1991) who reported that average kid mortality rate was (13.04 $\pm 0.05 \%)$. Chowdhury et al. (2002) reported that kid mortality rate were $70 \%$ which is lower than that of present study. Paul (2014) reported that average kid mortality rate of Black Bengal goat in NBF (Nucleas Breeding Flock in Bangaldesh Agricultural University) was $10 \pm 0.02 \%$ which is nearly similar with the study but lower than Modhupur and Nilphamari which were $31.03 \pm 0.05$ and $28.78 \pm 0.08 \%$ respectively. Lower kid mortality rate in NBF may be due to good management practices.

Table 7. Performance status of Black Bengal goats

\begin{tabular}{|c|c|c|c|c|c|c|c|}
\hline \multirow{2}{*}{ Traits } & \multicolumn{5}{|c|}{ Mean \pm SE } & \multirow{2}{*}{$\begin{array}{c}P \\
\text { Value }\end{array}$} & \multirow{2}{*}{$\begin{array}{l}\text { Level of } \\
\text { significance }\end{array}$} \\
\hline & Overall & Sadar & Fulbaria & Trishal & Muktagacha & & \\
\hline $\begin{array}{l}\text { Body weight at } 3 \\
\text { month }(\mathrm{kg})\end{array}$ & $4.67 \pm 0.15$ & $4.88 \pm 0.31$ & $4.62 \pm 0.38$ & $4.52 \pm 0.25$ & $4.63 \pm 0.29$ & 0.845 & Non significant \\
\hline $\begin{array}{l}\text { Body weight at } 6 \\
\text { month }(\mathrm{kg})\end{array}$ & $7.12 \pm 0.14$ & $6.71 \pm 0.46$ & $7.23 \pm 0.24$ & $7.27 \pm 0.17$ & $7.18 \pm 0.24$ & 0.517 & Non significant \\
\hline Litter size & $1.76 \pm 0.75$ & $1.73 \pm 0.16$ & $1.95 \pm 0.18$ & $1.67 \pm 0.19$ & $1.65 \pm 0.17$ & 0.57 & Non significant \\
\hline
\end{tabular}

\section{Conclusion}

The study indicates acute shortage of Black Bengal breeding bucks in the representative rural areas of Bangladesh, which may be the overall situation in the country. This scarcity gradually may reach to a severe level. Therefore, system for the production of meritorious Black Bengal breeding bucks and their distribution in the rural Bangladesh may urgently be called on.

\section{References}

Alam MK (2006). Characterization and performance evaluation of white goat in some selected areas of Bangladesh. MS Thesis, Department of Animal Breeding and Genetics, Bangladesh Agricultural University, Mymensingh.
Amin MR, Husain, SS and Islam ABMM (2001). Reproductive peculiarities and litter weight in different genetic groups of Black Bengal does. Asian-Australian Journal of Animal Science, 14 (3): 297-301.

Bangladesh Economic Review (2014). Finance Division, Ministry of Finance, Government of The People's Republic of Bangladesh.

Chowdhury SA, Bhuiyan MSA and Faruque S (2002). Rearing Black Bengal goat under semi-intensive management. 1. Physiological and reproductive performances. Asian-Australian Journal of Animal Science, 15: 477-84.

Choudhury MP, Sarker SC, Islam F, Ali A, Bhuiyan AKFH, Ibrahim MNM and Okeyo AM (2012). Morphometry and performance of Black Bengal goats at the rural community level in Bangladesh. Bangladesh Journal of Animal Science, 41(2): 83-89. 


\section{Breeding and production performance of goats}

Devendra C and Burn M (1983). Goat Production in the Tropics (Revised Edn.). Commonwealth Agricultural Bureaux, U.K. pp. 16.

FAO (2013). FAO Production Year Book 2013. Food and Agriculture Organization of United Nations, Rome, Italy.

Husain SS, Amin MR and Islam ABMM (1998). Goat production and its breeding strategy in Bangladesh. Proc. 1st National Workshop on Animal Breeding, BAU, Mymensingh, Bangladesh. pp. 17-36.

Islam MR, Amin MR, Kabir AKMA and Ahmed MU (2009). Comparative study between semiintensive and scavenging production system on the performance of Black Bengal goat. Journal of Bangladesh Agricultural University, 7 (1): 7986.

Jana C, Rahman FH, Mondal SK and Singh AK (2014). Management Practices and Perceived Constraints in Goat Rearing in Burdwan District of West Bengal. Indian Research Journal of Extension Education, 14 (2)

Kanaujia, A.S. and Pander BL (1988). Heterosis in some economic traits in Beetal and Black Bengal crosses. Indian Journal of Animal Science, 58: 127-129

Khandoker MAMY, Apu AS, Husain SS and Notter DR (2011). A baseline survey on the availability of Black Bengal breeding bucks in different districts of Bangladesh. Journal of Bangladesh Agricultural University, 9 (1): 91-96.

Mia MM (1993). A comparative study on the performance of Black Bengal, Barbari, AngloNubian and Black Bengal $\times$ Barbari goats. MS thesis, Department of Animal Breeding and Genetics, Bangladesh Agricultural University, Mymengingh, Bangladesh.

Paul RC, Rahman ANMI, Debnath S, Khandoker MAMY (2014). Evaluation of productive and reproductive performance of Black Bengal goat. Banglaesh Journal of Animal Science, 43(2): 104-111.

SAS 2004: Statistical Analysis System, Version 9.1.3, Copyright (C) 2002-2004 by SAS Institute, Inc, Cary, NC, USA.

Singh CSP, Mishra HR, Sharma BD, Mukherjee DK and Singh DK (1979). A note of body measurements in Black Bengal goats. Indian Journal of Animal Science, 49: 669-671.

Tsedeke KK (2007). Production and Marketing Systems of Sheep and Goats in Alaba, Southern Ethiopia. MSc Thesis submitted to University of Hawassa, Hawassa.

Wilson RT (1988). Reproductive performance of African indigenous small ruminants under research station and traditional management. In: Proceedings of the $6^{\text {th }}$ World Conference on Animal Production. World Association of Animal production. Helsinki, Finland. P. 585. 